\title{
Barramundi, Lates calcarifer (Bloch, 1790): A New Dimension to the Fish Farming in Coastal Bangladesh
}

\author{
Siddik MAB ${ }^{1 *}$, Islam MA ${ }^{2}$, Hanif MA ${ }^{1}$, Chaklader $M^{1}$ and Kleindienst $\mathbf{R}^{3}$
}

${ }^{1}$ Department of Fisheries Biology and Genetics, Patuakhali Science and Technology University, Patuakhali-8602, Bangladesh

${ }^{2}$ Department of Marine Fisheries and Oceanography, Patuakhali Science and Technology University, Patuakhali-8602, Bangladesh

${ }^{3}$ Department of Environment and Agriculture, Curtin University, 1 Turner Avenue, Bentley, WA 6102, Australia

\begin{abstract}
Barramundi, Lates calcarifer (Bloch, 1790) is one of the most commercially important species world-wide, with aquaculture of this species being relatively new in Bangladesh. This paper outlines the on growing farming systems of barramundi, its cultural constraints, economic significance, and availability in coastal Bangladesh. Although the farming practice of this species is relatively new, it is gaining prime preference among the consumers due to its nutritive values, taste and high flesh content compared to other commercially important species available in the entire coastal area. Farmers are following semi-intensive and extensive farming system along with other species due to the lack of seed in Bangladesh except some ordinary nurseries which rear natural sources fertilized eggs and fry to fingerling size. Overall, a shift from large scale capture fishery to culture across the southwestern part of Bangladesh marks an important emerging trend of barramundi farming in this area.
\end{abstract}

Keywords: Farming system; Cultural constraints; Availability; Lates calcarifer; Bangladesh

\section{Introduction}

The species of the Latidae family occupy a significant quantitative position among all demersal fishery resources of the world. There are 13 species belonging to 3 genera of the family Latidae available worldwide [1]. Lates calcarifer is one of the species of the family Latidae found in the estuarine systems on the coast of Bay of Bengal, Bangladesh [2,3]. Its distribution covers the Indo-West Pacific regions: eastern edge of the Persian Gulf to China, Taiwan and southern Japan, southward to southern Papua New Guinea and northern Australia [4]. This species is known by various common names in different parts of its range, including "barramundi" in much of Asia and "bhetki/ coral" in Bangladesh and India. The average length of barramundi generally varies between $29-60 \mathrm{~cm}$ and the weight ranges up to 60.0 $\mathrm{kg}$ [4]. Huda [5] estimated a maximum length of up to $200 \mathrm{~cm}$. This species commonly occurs in marine, fresh water and brackish coastal environment and is a demersal catadromous fish [6] with depth ranges between $10-40 \mathrm{~m}$ [7]. The species is considered tropical, tolerant of temperatures from $15^{\circ} \mathrm{C}$ to $28^{\circ} \mathrm{C}$ [8], with $27^{\circ} \mathrm{C}$ being optimal for growth in an aquaculture setting [9].

Currently, barramundi is farmed in many countries, with major production in Southeast Asia, especially from small-scale coastal cage farms. Australia has also established large-scale barramundi farms as commercial aquaculture practice. Barramundi have also been introduced as aquaculture product to Iran, Guam, French Polynesia, the United States of America (Hawaii, Massachusetts) and Israel [10]. Although the coastal areas of Bangladesh are rich in fishery resources [11-15] but culture practice of this species in Bangladesh remained almost void and there was no reported information on barramundi farming. During the past few years, this species has received greater attention which is reflected by its increasing farming practice in southwestern coastal area of Bangladesh. The aim of the study was to investigate barramundi farming with its limitations, moreover, its economic importance and seasonal availability were also considered in the study.

\section{Materials and Methods}

\section{Study area}

The study covers the area of barramundi farming in southwestern region of Bangladesh specifically in Satkhira district (Figure 1) in conjunction with the consideration of its markets. Lates calcarifer, owing to its catadromous behavior, barramundi spends most of their life in upper zone mainly in the freshwater river systems of southern Bangladesh. During spawning season, the fish migrate to brackish water, specifically in the downstream Sundarban mangrove area and further into oceanic waters. In Bangladesh, commercially fished barramundi are found in large volumes at Sonarmoor wholesale market $\left(22^{\circ} 19^{\prime} 04.0^{\prime \prime} \mathrm{N}, 89^{\circ} 06^{\prime} 20.6^{\prime \prime} \mathrm{E}\right)$, Satkhira, Khulna (Figure 2) near Sundarban. In retail markets of this area, both cultured and wild caught barramundi are available, but the majority of the fish in the study area are produced at a large shrimp farm as a secondary product. Almost all aquaculture farms are located in the southwestern Bangladesh.

\section{Results and Discussion}

In Bangladesh, the farming practice of Barramundi is new, confined in certain areas but increasing due to its market demand resulted from the rich nutritional quality, alluring taste and high flesh quantity. To support this trend, the decrease in wild capture quantities of barramundi has accelerated interest in cultured product to meet the growing demand.

*Corresponding author: Siddik MAB, Department of Fisheries Biology and Genetics, Patuakhali Science and Technology University, Patuakhali-8602, Bangladesh, Tel: +61450965212; E-mail: siddik@pstu.ac.bd

Received November 11, 2016; Accepted December 12, 2016; Published December 14, 2016

Citation: Siddik MAB, Islam MA, Hanif MA, Chaklader MR, Kleindienst R (2016) Barramundi, Lates calcarifer (Bloch, 1790): A New Dimension to the Fish Farming in Coastal Bangladesh. J Aquac Res Development 7: 461. doi: 10.4172/21559546.1000461

Copyright: @ 2016 Siddik MAB, et al. This is an open-access article distributed under the terms of the Creative Commons Attribution License, which permits unrestricted use, distribution, and reproduction in any medium, provided the original author and source are credited. 


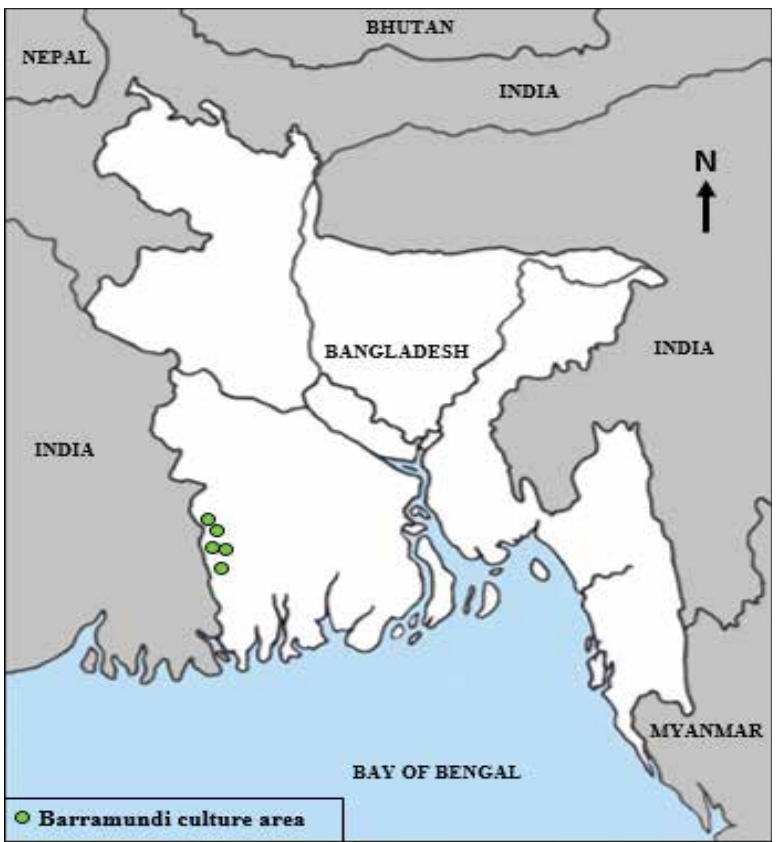

Figure 1: Map showing the barramundi, Lates calcarifer (Bloch, 1790) culture areas in Satkhira, Bangladesh.

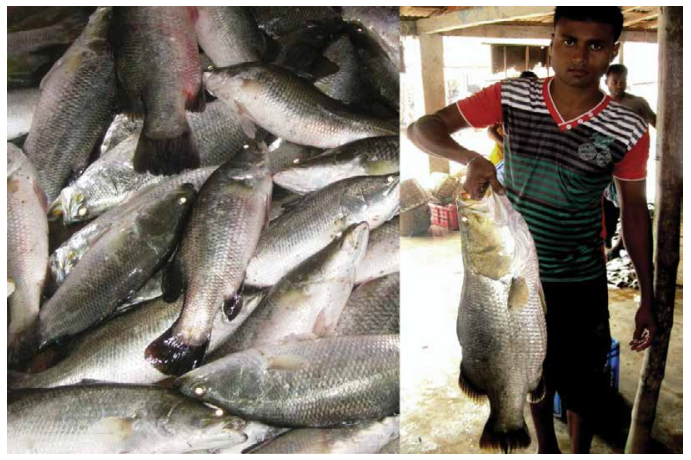

Figure 2: Barramundi, Lates calcarifer (Bloch, 1790) at Sonarmoor wholesale market in Satkhira, Bangladesh.

\section{Farming system and constraints}

Recently, barramundi has established in the southern part of Bangladesh, more specifically, in the southwestern coastal area in semi-intensive and extensive farming systems. Techniques for fry production of barramundi were developed in Thailand in the 1970s and further developed by several research institutes in the Philippines, Singapore, Hong Kong, and Australia [16]. To date, there are no wellestablished barramundi hatcheries found in Bangladesh. The exception is a small number of nurseries that rear wild sourced fertilized eggs and fry to fingerling size. These nurseries are mostly located in Kaliganj upazila under Satkhira district; therefore, the major source of fry and fingerlings is derived from natural coastal waters. Coastal water estuaries (Ganges delta) are considered as major spawning, nursery and feeding grounds [12-14,17-19] of diversified fish species including barramundi. Furthermore, mangroves provide one of the most productive zones of coastal water for fisheries and aquaculture development [20]. Barramundi fry and fingerlings are collected from the coastal Sundarban area, especially during the post monsoon period when shrimp post larvae (PL) are also abundant. Collection methods are predominantly with indigenous equipment including set bag net and small mosquito net [21-23]. These collected fry and fingerlings are sold in selected markets. Farm owners use these wild caught and nursery grown fry and fingerlings in their coastal brackish water farms.

In semi-intensive farming systems in Bangladesh, farms are usually divided into two sections; the large one is used for shrimp culture, in which native tilapia are used as live food for barramundi. These fish are highly fecund, constantly producing larvae in these ponds. The small section of the farm is used to stock barramundi until the end of shrimp farming. Between July and September, almost all shrimp are harvested and sold, with the whole farm being dedicated to barramundi farming until the next season of shrimp culture. Barramundi are restocked during December to February. The omnivorous juvenile stage and the carnivorous post-juvenile stage of barramundi greatly influence the feed input. There are no species specific artificial feeds available in the market for barramundi in Bangladesh and the farmers depend on locally made food and live food (tilapia) that is grown concurrently with the shrimp farm. Being extensive farming systems, tidal water allows input of various invertebrate larvae such as shrimp, prawn larvae and crabs to supply barramundi fry with live food. Fish will be grown out for a minimum of six months to a maximum of two years.

In practice, the limiting factors in profitability in barramundi farming is mainly due to the lack of quality, commercial feed and lack of hatchery produced fingerlings. Other factors impacting profitability and viability include costly live food inputs and it's the heavy losses caused by barramundi's voracious carnivorous behavior.

\section{Economic significance and availability}

The abundance of barramundi in the local and national markets of Bangladesh is comparatively higher in the post monsoon period than other periods where a significant proportion comes from fish farms. During the other periods, wild capture fisheries contributes substantial portion. The fresh fishes are sold in local markets for 250-560 BDT per $\mathrm{kg}(1 \mathrm{US} \$=78 \mathrm{BDT})$. It is evident that the price per $\mathrm{kg}$ of this species differs with seasonality, its individual weight and market availability. Availability and price of barramundi in Sonarmoor wholesale fish market over the duration of 12 months are shown in Figure 3. This wholesale market is the prime fish market for barramundi marketing in Bangladesh.

Considering the high market price and economic importance, a

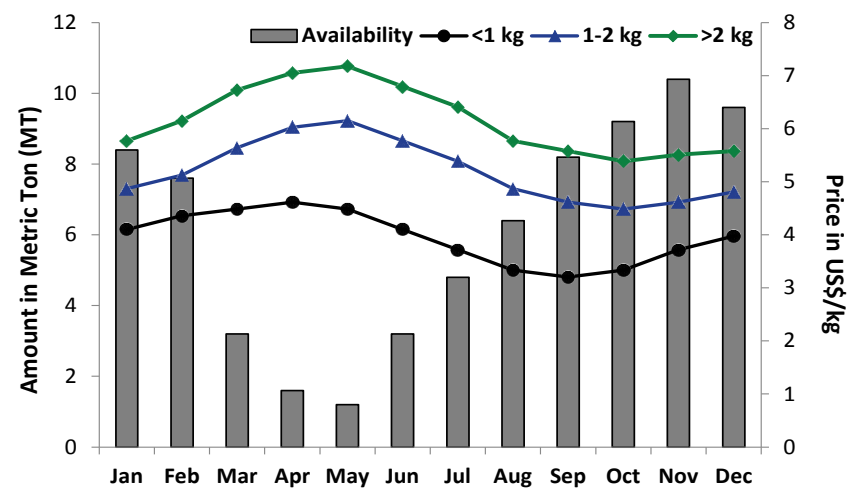

Figure 3: Availability (average amount per day) and price (1 US $\$=78$ BDT) of barramundi, Lates calcarifer in Sonarmoor wholesale fish market, Satkhira, Bangladesh. 
Citation: Siddik MAB, Islam MA, Hanif MA, Chaklader MR, Kleindienst R (2016) Barramundi, Lates calcarifer (Bloch, 1790): A New Dimension to the Fish Farming in Coastal Bangladesh. J Aquac Res Development 7: 461. doi: 10.4172/2155-9546.1000461

detailed study of barramundi is crucial to get a better understanding of its availability, biology, habitats, ecology and also culture system of this species in Bangladesh.

\section{Conclusion and Recommendations}

A shift from entirely shrimp culture to small scale barramundi culture in the southwestern coastal region of Bangladesh, the northern tip of the Bay of Bengal, continues marking an important promising trend for the barramundi aquaculture of this area.

The major facilities that need addressing to make barramundi an ideal farming candidate of Bangladesh are:

1. Establishment of adequate numbers of hatcheries to meet the demand of seed;

2. Introducing selective breeding to improve qualitative and quantitative attributes of the fish;

3. Establishment of commercial feed industry to produce speciesspecific feed; and

4. Ensure high-quality marketing facilities to expand market demand at both national and international level.

\section{References}

1. Otero O (2004) Anatomy, systematics and phylogeny of both recent and fossi latid fishes (Teleostei, Perciformes, Latidae). Zool J Linn Soc 141: 81-133.

2. Hanif MA, Siddik MAB, Chaklader MR, Nahar A, Mahmud S (2015) Fish diversity in the southern coastal waters of Bangladesh: Present status, threats and conservation perspectives. Croat J Fish 73: 251-271.

3. Rahman AKA (1989) Freshwater fishes of Bangladesh. Zoological Society of Bangladesh. Department of Zoology, University of Dhaka, Bangladesh.

4. Ilham I, Siddik MAB, Fotedar R (2016) Effects of organic selenium supplementation on growth, accumulation, haematology and histopathology of juvenile barramundi (Lates calcarifer) fed high soybean meal diets. Biol Trace Elem Res 174: 436-447.

5. Huda MS, Haque ME, Babul AS, Shil NC (2003) Field guide to finfishes of Sundarban, Aquatic resources division, Sundarban, Boyra, Khulna, Bangladesh.

6. Riede K (2004) Global register of migratory species - From global to regional scales. Federal Agency for Nature Conservation, Bonn, Germany.

7. Whitehead PJP (1984) Centropomidae. FAO species identification sheets for fishery purposes. Western Indian Ocean (Fishing Area 51) Rome.

8. Baensch HA, Riehl R (1985) Aquarien atlas. Band 2. Mergus, Verlag für Naturund Heimtierkunde $\mathrm{GmbH}$, Melle, Germany.
9. Cheung WL, Watson R, Pauly D (2013) Signature of ocean warming in global fisheries catch. Nature 497: 365-368.

10. FAO (2016) Food and Agriculture Organization. Cultured Aquatic Species Information Programme. FAO Fisheries and Aquaculture Department [online], Rome.

11. Siddik MAB, Hanif MA, Chaklader MR, Nahar A, Fotedar R (2016) A multivariate morphometric investigation to delineate stock structure of gangetic whiting, Sillaginopsis panijus (Teleostei: Sillaginidae). SpringerPlus 5: 520.

12. Siddik M, Chaklader M, Hanif M, Islam M, Sharker M, et al. (2016) Stock identification of critically endangered olive barb, Puntius sarana (Hamilton, 1822 ) with emphasis on management implications. J Aquac Res Development 7: 411.

13. Chaklader MR, Siddik MAB, Nahar A (2015) Taxonomic diversity of paradise threadfin Polynemus paradiseus (Linnaeus, 1758) inhabiting southern coastal rivers in Bangladesh. Sains Malaysiana 44: 1241-1248.

14. Siddik MAB, Chaklader MR, Hanif MA, Islam MA, Fotedar R (2016) Lengthweight relationships of four fish species from a coastal artisanal fishery southern Bangladesh. J Appl Ichthyol 32: 1300-1302.

15. Siddik MAB, Chaklader MR, Hanif MA, Nahar A, Ilham I, et al. (2016) Variation in the life-history traits of a Schilbid catfish, Clupisoma garua (Hamilton, 1822) in the coastal waters of southern Bangladesh. Chinese Journal of Oceanology and Limnology.

16. Grey DL (1987) An overview of Laces calcarifer in Australia and Asia. In: Copland JW, and Grey DL (eds). Management of wild and cultured seabass/ barramundi (Laces calcarifer): proceedings of an international workshop held at Darwin NT, Australia 20: 15-21.

17. Chaklader M, Nahar A, Siddik M, Sharker R (2014) Feeding habits and die composition of Asian Catfish Mystus vittatus (Bloch, 1794) in shallow water of an impacted coastal habitat. World J Fish Mar Sci 6: 551-556.

18. Siddik MAB, Nahar A, Ahamed F, Masood Z, Hossain MY (2013) Conservation of critically endangered Olive Barb Puntius sarana (Hamilton, 1822) through artificial propagation. Our Nat 11: 96-104.

19. Siddik MAB, Hanif MA, Chaklader MR, Nahar A, Mahmud S (2015) Fishery biology of gangetic whiting Sillaginopsis panijus (Hamilton, 1822) endemic to Ganges delta, Bangladesh. Egypt J Aquat Res 41: 307-313.

20. Kumary KSA (2016) Comparative ecology of backwater and mangrove environments of Kayamkulam Lake, Kerala. J Aquac Res Development 7: 438.

21. Islam MA, Haque MM, Ahmed ZF, Mahmud S, Nahar A, et al. (2015) Coastal set bagnet fishery in the Payra river, Bangladesh and its impact on fisheries and biodiversity. J Coast Life Med 3: 295-301.

22. Hanif MA, Siddik MAB, Chaklader MR, Mahmud S, Nahar A, et al. (2015b) Biodiversity and conservation of threatened freshwater fishes in Sandha River, south west Bangladesh. World Appl Sci J 33: 1497-1510.

23. Hanif MA, Siddik MAB, Nahar A, Chaklader MR, Rumpa RJ, et al. (2016) The current status of mall Indigenous Fish Species (SIS) of River Gorai, a Distributary of the River Ganges, Bangladesh. J Biodivers Endanger Species 4: 2 . 